\title{
Race, National Identity and Responses to Muhammad Ali in 1960s Britain
}

\author{
Martin Johnes (Swansea University)
}

From the 1990s onwards, Muhammad Ali was celebrated in the USA primarily as a humanitarian figure who had done much to promote racial understanding and reconciliation. The power of this image, despite evidence of Ali's prejudices, owed much to a nation trying to right some wrongs in its racial history and acknowledge how he had been hated by many Americans in the 1960s. ${ }^{1}$ In contrast, the British media has painted an affectionate picture of the UK's relationship with the boxer. ${ }^{2}$ This suited Ali too since it reinforced the idea of American prejudice that he sought to challenge. He recorded in his 1976 autobiography - a ghost-written text intended to promote Ali's politics - that he had fallen in love with England. He recalled that he had been treated on his first visit, 'so warm, so friendly' and with a 'kindness and courtesy' that he never experienced in the USA. He thus regarded, he claimed, the country as his second home. ${ }^{3}$

Inevitably, the reality was more complex; in 1960s Britain Ali was judged through a lens of national identity and race that was not always warm or affectionate. On the occasion of his first fight in the UK, against Henry Cooper in 1963, Ali's boasting offended many for whom it typified an American excess out of sorts with British modesty. His boasting did, however, create significant publicity, turning Ali into a popular celebrity amongst the young

\footnotetext{
${ }^{1}$ For an analysis of this construction of Ali see Michael Ezra, Muhammad Ali: The Making of an Icon (Philadelphia: Temple University Press, 2009). The literature on Ali is large but probably the definitive biography is Thomas Hauser, Muhammad Ali: His Life and Times (London: Portico, 1991). On his cultural significance see Gerald Lyn Early, The Muhammad Ali Reader (Hopewell: Ecco Press, 1998); Elliot J. Gorn (ed.), Muhammad Ali: The People’s Champ (Urbana: University of Illinois Press, 1995); Mike Marqusee, Redemption Song: Muhammad Ali and the Spirit of the Sixties (New York: Verso, 2000).

${ }^{2}$ When Ali Came to Britain, ITV, 16 January 2012. For a narrative of Ali's reception in the UK see Michael Tanner, Ali In Britain (Edinburgh: Mainstream, 1995).

${ }^{3}$ Muhammad Ali, The Greatest: My Own Story (St Albans: Mayflower, 1976), 132. For a discussion of the book and the views of Ali's biographers towards it see Michael Ezra, 'Battles for control over Muhammad Ali's Career and Image', in Michael E. Lomax (ed), Sport and the Racial Divide: African American and Latino Experience in an Era of Change (Jackson: University Press of Mississippi, 2008), 23-54, at 46-8.
} 
and those attracted by his variance from the conventions of the time. Race rarely entered the public discussions of Ali but it was never irrelevant and, at a time of concerns around rising immigration, racial stereotypes encouraged a view of him as brash and immature. By 1966, when Ali fought for a second and third time in Britain, he was world champion and a deeply controversial figure following his conversion to Islam and opposition to the Vietnam War. Yet neither issue had the significance in the UK that they did in the USA and his British fan base continued to grow. Even amongst those who disagreed with his politics, there was no public demonization of him but rather a muted disapproval. He was, however, an inspiration to Britons of colour and those who believed in the need for radical challenges to the world's problems. As such, Ali is an example of how ideas, fears and hopes around race crossed back and forth across the Atlantic and the need for its British historians to ensure their accounts are outward looking and de-domesticised.

The competing British views of Ali typified how attitudes towards race and immigration in the UK were complex and contradictory. There was some acceptance but there was also considerable prejudice and a profound sense of racial difference. Historians have disagreed over whether the state or public were more illiberal but large sections of both ultimately became concerned with keeping the UK white, even if they believed in the concept of racial equality. ${ }^{4}$ Ali's status in the UK was framed by this context. Yet, as an American celebrity, he also transcended the normal concerns around race. He was not an immigrant and thus not symbolic of changes in the racial makeup of Britain, making it quite possible for even open racists to admire and celebrate his skills. Ali’s British reception thus confirms the argument of Kushner that attitudes to people of colour were 'complex and can only be explained satisfactorily by the broadest of contextualization, which includes, alongside racism, factors such as gender and class and global, national and local pride'. ${ }^{5}$ As such, race alone can never be the sole lens through which the reception and experience of people of colour are analysed. But nor should the absence of race and prejudice in the public treatment

\footnotetext{
${ }^{4}$ The best overview of race and black experiences in this period is Kennetta Hammond Perry, London is the Place for Me: Black Britons, Citizenship and the Politics of Race (Oxford: Oxford University Press, 2016). For state prejudices see Kathleen Paul, Whitewashing Britain: Race and Citizenship in the Postwar Era (Ithaca: Cornell University Press, 1997). For the argument the state was responding to popular demand see Randall Hansen, Citizenship and Immigration in Post-war Britain (Oxford: Oxford University Press, 2000). On popular prejudices see Chris Waters, 'Dark Strangers’ in our Midst: Discourse on Race and Nation in Britain, 1947-63’, Journal of British Studies, 36 (1997): 207-38, and Marcus Collins, 'Pride and Prejudice: West Indian Men in Mid-Twentieth-Century Britain’, Journal of British Studies, 40, 3 (2001): 391-418. For a more nuanced view see Mica Nava, 'Sometimes Antagonistic, Sometimes Ardently Sympathetic: Contradictory Responses to Migrants in Postwar Britain’, Ethnicities, 14, 3 (2013): 458-80.

${ }^{5}$ Tony Kushner, We Europeans? Mass-Observation, 'Race' and British Identity in the Twentieth Century (Aldershot: Ashgate, 2004), 32.
} 
of black men and women, as was often the case with Ali in the UK, be taken as evidence of an absence of racial tensions. Like the celebrations of Ali and the criticisms of his Americanism, beneath articulations or appearances of equality were often deep prejudices.

To explore these attitudes, this paper draws upon a wide variety of media sources from the local and national press, to boxing publications and television outputs. For the majority, boxing was a mediated experience, something read about and watched rather than witnessed first-hand. Ali's rise coincided with the coming of mass television ownership, allowing him to reach audiences that his predecessors in the ring had not. It was thus through the mass media that Ali became both a hero and villain and he was as much a media figure as a boxer. Of course, the media is not a straightforward guide to popular opinion. Yet, in a context where the spatially-concentrated nature of immigration meant that first-hand interaction with people of colour was limited, television was a 'site of racial formation', offering a space where racial images inspired and entertained but also alarmed and reinforced perceptions of difference. ${ }^{6}$ In the 1960s, Ali was very much part of that and an influential figure in shaping how the British public thought about race, for better and worse.

\section{Cooper versus Ali 1963}

In the early 1960s, both British race relations and boxing stood at a crossroads. Boxing was a sport in decline. Its violence was under scrutiny from those who felt it inappropriate in a modern society; affluence had reduced the numbers interested in taking a beating for a living and the game was increasingly focussed on its leading stars rather than the circuit of semiprofessional fights in small halls that had dominated the sport in the first half of the twentieth century. Paradoxically, there were also no British boxers of world calibre in the 1960s. ${ }^{7}$

British boxing was, however, like wider society, becoming more diverse. The 1948 British Nationality Act had enshrined everyone in the Commonwealth's existing right to settle in the UK, paving the way for a period of sustained immigration. By 1966 there were an estimated 797,000 people of colour living in Britain who were born in the Caribbean, India and Pakistan. ${ }^{8}$ Amongst the immigrants were boxers from West Africa and the West Indies, attracted to the financial opportunities the UK offered to fight professionally. The diversity of boxing was further increased as the sons of a few 1940s and 50s immigrants

\footnotetext{
${ }^{6}$ Rob Waters, 'Black Power on the Telly: America, Television, and Race in 1960s and 1970s Britain', Journal of British Studies, 54 (2015), 947-70, p. 949. Gavin Schaffer, The Vision of a Nation: Making Multiculturalism on British Television, 1960-80 (Basingstoke, 2014), 7.

${ }^{7}$ The historiography of boxing in the UK is relatively limited. For an overview see Martin Johnes and Matthew Taylor, 'Boxing in History', Sport in History, 31, 4 (2011): 357-62.

${ }^{8}$ A. H. Halsey (ed), Trends in British Society since 1900 (London: Macmillan, 1972), 459.
} 
turned to the fight game to make a living in a world where well-paid work was often extremely difficult to find for those of colour. By the early 1960s, a quarter of professional boxers registered in the UK were black. However, they faced significant prejudices and struggled to build careers against the prejudices and preconceptions of fans and promoters. Black boxers were regarded as poor box-office draws and judged through contradictory racial stereotypes that simultaneously viewed them as having an unfair physical advantage over white fighters but also unable to take a punch. ${ }^{9}$ Just as the historic racial hierarchies of Empire shaped attitudes to immigrants in an era of decolonization, so too were black boxers entrapped by the remnants of a history of white hostility towards professional fighters of colour. $^{10}$

It was in this context that heavyweight Henry Cooper, an old-style slugger with ambitions for a world title, was lined up in 1963 to fight Ali, then known as Cassius Clay. Ali was a confident 21-year-old who was gaining a reputation for both 'his ranting and his raving' and his skills. ${ }^{11}$ The previous year, the British Boxing News Annual produced an article about his chances of becoming world champion and predicted he would become the most talked about boxer of 1963, whether he made it to the top or not. It concluded 'the Fight Game needs boys like Cassius Clay, the box-fighter who is also a showman; the boxer with ring ability and the flair for making the boxing writers work hard and the fans to read and wonder'. ${ }^{12}$ Before Ali had even fought in the UK, one British fan declared in a letter to the Boxing News that 'Clay is the greatest heavyweight ever'. ${ }^{13}$

It was the ranting and raving that came to define Ali's first British fight. Before Ali's arrival, promoter Jack Solomons advised people to 'commence training' their ears and to get the ear plugs out. ${ }^{14}$ Such hype was needed to justify the choice of Wembley stadium as a venue but the fact that the promoter had chosen there at all said something about his confidence that Ali would be a pull. This was rooted in the fact that he was completely different to anyone else on the international boxing circuit. Ali was articulate and entertaining; he played the media, talking in rhyme about himself and his skills and making

\footnotetext{
${ }^{9}$ On the wider history of boxing and race in this period see Martin Johnes and Matthew Taylor, 'Boxing, Race and British National Identity, 1945-63' (forthcoming).

${ }^{10}$ On such attitudes in a US historical context see Louis Moore, I Fight for a Living: Boxing and the Battle for Black Manhood, 1880-1915 (Urbana: University of Illinois Press, 2017). For how they played out in the UK see Theresa Runstedtler, Jack Johnson, Rebel Sojourner: Boxing in the Shadow of the Global Color Line (Berkley: University of California Press, 2012), ch. 3.

${ }^{11}$ Henry Cooper, Henry Cooper: An Autobiography (London: Cassell, 1972), 92.

12 'Will it be King Clay?', 1963 Boxing News Annual and Record Book (London: Ring Publications, 1963), 7-8.

${ }^{13}$ Letter in Boxing News, 29 March 1963.

14 'Cassius Clay is her on Monday’, Boxing News, 24 May 1963, 2.
} 
grand predictions that he would knock Cooper out in first five rounds and then three. 'I've been yelling on the television, hollering on the radio, telling them I'm the greatest, but they won’t believe me' he declared. ${ }^{15}$ As well as displaying such overt confidence, Ali also showed a lack of respect to Cooper who he called 'a bum and a tramp' who had no right to be in a ring with him. ${ }^{16}$ He was not always much nicer about Britain either, saying in one television interview that the cars were too small, the streets were too narrow and the girls not as pretty as home. ${ }^{17}$

A BBC boxing correspondent remembers these claims were not always taken seriously but they did make a news story and the fight became a major media event. Many were genuinely angry at the American's attitude and Ali was booed on the street. The South Wales Argus argued the boasting had not 'gone down well with the British public, and nothing would please them more than to see Clay get a big hiding'. ${ }^{18}$ A letter to the Daily Mirror declared: 'Who is this obnoxious Cassius Clay? And why is he permitted to invade our shores with his nonsensical claptrap? ${ }^{19}$ Even a Labour MP made a swipe at Ali when calling the Chancellor 'a most agreeable and modest opponent' in a finance debate. ${ }^{20}$ The Boxing News published a page of poems from fans attacking Ali. The paper declared that Cooper would be

doing millions of fight fans the world over a big favour if he manages to halt the upward trend of big-talking American Cassius Marcellus Clay ... For the Louisville Lip has, with his pathetic poetry and degrading insults to the British champ, turned everybody into a Cooper fan.

Yet the paper also understood that the 'big-talking' was more about money and publicity and beneath it was a fast and able fighter. ${ }^{21}$

At this point in his career, Ali was very popular in the US, where his good looks, poetry, exuberance and sense of humour made him the kind of star American television audiences loved. ${ }^{22}$ In contrast, such seemingly-American qualities went down less well in the

\footnotetext{
${ }^{15}$ Brian Glanville, 'Cooper Banks on his Left', Sunday Times, 16 June 1963, 21.

16 'Snubbed Clay Cuts Cooper's Rations to Three Rounds', Daily Mail, 18 June 1963, 15.

${ }^{17}$ Unaccredited footage on When Ali Came to Britain, ITV, 16 January 2012.

18 South Wales Argus, 18 June 1963.

19 'Sportview', Daily Mirror, 31 May 1963, 29.

${ }^{20}$ House of Commons Debate, 28 June 1963, vol. 679 c1878.

${ }^{21}$ Various in Boxing News, 14 June 1963.

${ }^{22}$ Kasia Boddy, Boxing: A Cultural History (London: Reaktion, 2008$), 327$.
} 
UK. There existed amongst the post-war British elite a fear that American global influence was too strong and eroding British cultural values. Indeed, Americanization had become 'a cliché of popular British discourse'. ${ }^{23}$ This was not just rooted in concern for a fading British eminence but also in a long-standing dislike of aspects of American culture and, as the reactions to Ali showed, this extended far beyond the elite. The 1950s rise of rock'n'roll and youth culture, often perceived to be shallow, disrespectful, and sometimes immoral, had intensified a trend that interwar Hollywood had begun and brought such concerns into the homes of some working-class families who worried about the behaviour and manners of their teenage children. The dislike of Ali’s boasting typified a certain British view of American culture as arrogant, brash, exuberant and consumerist, lacking in the modesty that was thought to characterize the UK. Ali seemed to embody all of these characteristics, not least because his activities were clearly intended to raise his box-office appeal. Britishness, in contrast, had been reconstructed in the 1930s and 40s around ideas of ordinariness and a quieter everyday existence and the war itself had become a conflict to defend that culture and way of life. ${ }^{24}$ Indeed, there were echoes of attitudes towards Hitler in how the press spoke of Ali. 'The British do not like a braggart and a bully who is not anything like as majestic as he proclaims' declared the Daily Express. ${ }^{25}$

Just as Ali symbolized US culture, Cooper was a representative of British culture rather than just Britain and this helped further boost interest in the fight. He was a modest old-fashioned fighter that encapsulated a British self-image of quiet determination and grit and a vision of the working class that was rooted in traditional values rather than the crass Americanism and commercialism that was often felt to be corrupting the masses. British sporting heroes had long since symbolized such ideas but in the post-war period this national self-image was being reinforced by the growing popular belief that Britain had stood alone in 1940 and both survived and won the war through its national character and tenacity. ${ }^{26}$ The

\footnotetext{
${ }^{23}$ Howard L. Malchow, Special Relations: The Americanization of Britain? (Stamford, 2011), p. 3. Also see Victoria de Grazia, Irresistible Empire: America's Advance through Twentieth-Century Europe (Cambridge: Belkapp Press, 2005). Adrian Horn, Juke Box Britain: Americanization and Youth Culture, 1945-1960 (Manchester: Manchester University Press, 2009). On resistance to Americanization see Richard Pells, Not Like Us: How Europeans Have Loved, Hated, and Transformed American Culture Since World War II (Oxford: Oxford University Press, 1997).

${ }^{24}$ John Baxendale, 'You and I - All of Us Ordinary People': Renegotiating 'Britishness' in Wartime', in Nick Hayes and Jeff Hill (eds), 'Millions Like Us': British Culture in the Second World War (Liverpool: Liverpool University Press, 1999), 295-322.

${ }^{25}$ Desmond Hackett 'Yes - Cassius in Five', Daily Express, 19 June 1963, 16.

${ }^{26}$ One product and cause of such beliefs was contemporary war films. See Jeffrey Richards, Films and British National Identity: From Dickens to Dad's Army (Manchester: Manchester University Press, 1997). For examples of sports heroes as symbols of working-class decency and national grit see Richard Holt, 'Heroes of the North: Sport and the Shaping of Regional Identity’, in Jeff Hill and Jack Williams (eds), Sport and Identity
} 
Daily Mail reported 'modest, likable Henry’ as saying that he expected to show that 'The Lip' was 'a better talker' than 'a fighter'. Its report could not help adding 'With the rest of Britain I hope that Cooper is right. If Britain's quiet man buttons the mouth from which little but childish abuse has poured for three weeks I'll join [promoter] Jack Solomons in his plans to lead the expected 55,000 crowds in There'll always be an England' ${ }^{27}$

Such defensiveness owed much to how the late 1950s and early 1960s was a period when many felt traditional British culture was under assault from different directions that extended beyond Americanization. The Cold War and decolonization had marginalized British global power, while the growth of the state was causing some individuals to feel powerless. Those who believed their old certainties were slipping away were further worried by declining deference, changing class, gender and community patterns and the growing visibility of people of colour on British urban streets. ${ }^{28}$ Even in sport, old markers of tradition were falling away; cricket had abolished its amateur-professional distinction in 1963 and introduced one-day matches, while football ended its maximum wage in 1961. In this context, Ali seemed to be yet another affront to traditional British ways of doing things. One boxing fan recalls a generation gap in attitudes to Ali at this time, with younger ones more taken with Ali's unconventional approach. ${ }^{29}$ Outsiders also saw the link between the fight and wider British culture. A writer in the Washington Evening News claimed the British delusion that Cooper could win was 'in keeping with the image of a nation that still considers itself a world power. The British put on a front of sophistication but inevitably prove themselves to be the biggest pasties in creation. ${ }^{30}$

Yet, within Britain itself, the older generation was never quite as conservative or uniform as teenage rebels suggested and the shifting sands of the era were not just the realm of the young. Beneath the moral panic around rock'n'roll sometimes evident in the press was actually a more tolerant view of both young people and American culture. ${ }^{31}$ Working-class parents in particular gave financial and verbal support to teenage culture since it represented

\footnotetext{
in the North of England (Keele: Keele University Press, 1996), pp. 137-64. Martin Johnes and Gavin Mellor, 'The 1953 FA Cup Final: Modernity and Tradition in British Culture', Contemporary British History, 20, 2 (2006), 263-80. Richard Holt, 'Cricket and Englishness: The Batsman as Hero', in Richard Holt and J. A. Mangan (eds), European Heroes: Myth, Identity, Sport (London: Frank Cass, 1996), 48-69.

27 'Snubbed Clay Cuts Cooper's Rations by Three Rounds', Daily Mail, 18 June 1963, 15.

${ }^{28}$ For a discussion of such anxieties in a local context see Martin Johnes, Wales since 1939 (Manchester: Manchester University Press, 2012), chs. 4 and 5.

29 Tanner, Ali in Britain, 12, 13.

${ }^{30}$ Washington Evening News quoted in 'Sorry about those Pasty Faces!', Daily Mail, 31 May 1963, 22.

${ }^{31}$ Gillian A. M. Mitchell, 'Reassessing ‘the Generation Gap’: Bill Haley’s 1957 Tour of Britain, Intergenerational Relations and Attitudes to Rock ' $n$ ' Roll in the late 1950s', Twentieth Century British History, 24, 4 (2013): 573-605.
} 
an advance in living conditions and expectations. ${ }^{32}$ The 1963 Profumo scandal, which reached a climax in the weeks running up to the Ali-Cooper fight, had rocked the establishment and led people across classes and generations to become exasperated with its hypocrisy and lack of propriety. By then, the thrust to modernize had become a dominant trope in thinking about the British economy and it was increasingly being seen as something much of British life was in need of. One consequence was that even the Beatles won conservative plaudits in the early 1960s for their contribution to British prestige and tax revenue. ${ }^{33}$

There were those, too, of all ages who were rather taken by Ali. Despite the arrogance it might betray on a first reading, his demeanour and talk could also be read as humorous and a gentle dig at the straight-jacketed and stiff-upper-lip culture some in Britain also despised. The Daily Mail noted, 'Clay is a happy young man, half laughing at the way his publicity stunts are accepted, but half-dreaming that all he says is true'. ${ }^{34}$ Two weeks before it printed its page of abusive poems about Ali, Boxing News argued that he had 'taken London by storm', claiming that the American and the resulting publicity had been a 'shot in the arm' for British boxing. An editorial in the paper concluded that 'one cannot help but admire the confidence and cockiness which oozes from this young athlete'. Another writer in the same paper declared 'The fans love a personality. They have taken to Clay like a duck takes to water., 35

The inconsistency in the paper's position showed the degree of pantomime in the whole affair but it is also suggestive of the uncertainties and contradictions that surrounded British culture at this time. There were those rooted in the past, those who sought new futures and those who conceded a need for modernization but also feared what it might mean. These groups could not be neatly categorized by class or age but Ali had an impact on all.

The fight itself began well for Cooper but he then sustained a cut above his eye and Ali sensed victory, even declining to hold his arms up in the standard defensive pose. The British television commentator called this 'complete cheek' and claimed Ali was trying to make Cooper look small. Then, at the end of the fourth round, to deafening cheers from the crowd, Cooper knocked Ali down. ${ }^{36}$ He got to his feet but, in the subsequent interval, Ali's

\footnotetext{
${ }^{32}$ Selina Todd and Hilary Young, 'Baby-boomers to 'Beanstalkers': Making the Modern Teenager in Post-war Britain', Cultural and Social History, 9, 3 (2012): 451-467.

${ }^{33}$ Marcus Collins, “The Age of the Beatles': Parliament and Popular Music in 1960s Britain', Contemporary British History, 27, 1 (2013), 85-107.

${ }^{34}$ J. L. Manning, 'Mr .50 p.c. - That’s Cassius Clay', Daily Mail, 17 June 1963, 16.

${ }^{35}$ 'Gaseous Caseous' and 'Cassius Marcellus Is Here', Boxing News, 31 May 1963, 6 and 10.

${ }^{36}$ For a video of the fight and British commentary see 'Muhammad ali vs henry cooper',
} 
corner sneaked him some illegal smelling salts and ripped open a tear in his glove to buy him some more recovery time. ${ }^{37}$ But Cooper's cut was irreparable and in the fifth round Ali attacked aggressively. As the Mail put it, the crowd moved from screaming for 'Clay's blood' to shouting 'stop the fight' with Cooper beginning to look 'like the victim of a terrible road accident - a creature from a horror film'. ${ }^{38}$ The referee ended the contest and Ali held up five fingers to remind the crowd of his correct prediction of which round he would win in.

Cooper was cheered out of the ring and Ali was booed. An angry spectator who broke through the cordon aimed a blow at Ali and a mob surrounded his entourage's cars as they tried to leave the stadium. ${ }^{39}$ Boxing correspondents were unimpressed with Ali's performance, feeling he had failed to show any real quality. The Daily Mail went as far as proclaiming 'If this immature American boxer can be knocked down by a half-blind opponent with no reputation as a heavy puncher, then he should be matched more moderately'. ${ }^{40}$ The Express thought the ring had been 'filled with the courage and then the blood of a British champion' ${ }^{41}$

\section{Ali and British perceptions of race}

Outside boxing, the rising levels of immigration of the previous decade or so had brought complex reactions. Despite the large-scale immigration from Ireland and mainland Europe, public discussion of the phenomenon focussed on black and Asian people and the idea of a ‘colour problem'. ${ }^{42}$ Rooted in Britain's imperial history but now brought home and intensified as the Empire came to Britain, racial difference was accepted as common sense and this created a sense that British culture was being harmed by immigration. Black men were looked down upon as lazy, sexually irresponsible, sometimes violent, and a threat to a British way of life. ${ }^{43}$ This produced some extreme reactions amongst people of all ages, as evident in the youth-led race riots of 1958 and the popularity of Enoch Powell's 1968 rivers of blood speech across different generations. ${ }^{44}$ Yet overt racial prejudice was publicly frowned upon and some who argued against immigration maintained their concerns were

\footnotetext{
https://www.youtube.com/watch?v=Frn3rTj5DOY (accessed 5 September 2019).

${ }^{37}$ When Ali Came to Britain, ITV, 16 January 2012.

${ }^{38}$ Vincent Mulchrone, 'Stop the fight Says Liz', Daily Mail, 19 June 1963, 1.

${ }^{39}$ Ezra, Muhammad Ali: The Making of an Icon, 59.

40 Tanner, Ali in Britain, 28.

${ }^{41}$ Desmond Hackett, 'Yes - Cassius in Five', Daily Express, 19 June 1963, 16.

${ }^{42}$ Wendy Webster, Englishness and Empire, 1939-65 (Oxford: Oxford University Press, 2007), 149.

${ }^{43}$ On racial stereotypes see Collins, 'Pride and prejudice'. On the imperial roots of British racism see Bill Schwarz, The White Man's World (Oxford: Oxford University Press, 2011).

${ }^{44}$ On the role of youth in the Notting Hill riots see Felix Fuhg, 'Ambivalent Relationships: London's Youth Culture and the Making of the Multi-racial Society in the 1960s', Britain and the World, 11, 1 (2018), 4-26.
} 
cultural rather than racial. ${ }^{45}$ As Nava has demonstrated, contemporary studies found that racial attitudes were contradictory, complex and divided. ${ }^{46}$ A 1955 investigation claimed that the British population could be loosely divided into three with one third not prejudiced and one third extremely prejudiced, although a 1961 edition of the book downplayed the size of this latter group. ${ }^{47}$ Yet what also emerged from contemporary studies was how embedded the sense of racial difference was. Although many Britons felt racism was wrong, they still spoke and acted in ways that showed that race was rarely irrelevant and something perceived to run far deeper than mere skin colour. Even labelling and describing someone by their colour helped sustain racism because it perpetuated ideas of 'us' and 'them' and that racial differences were real rather than constructed. British reactions to immigration may have been contradictory but racism was endemic and embedded in British culture.

The success of black boxers had contributed to the racial stereotypes. A survey of mid-1950s Brixton argued that black proficiency in fields like boxing and jazz 'tended to reinforce local preconceptions associating colour with violence, sensuality and uninhibited behaviour in general'. In particular, black successes in boxing and the association between pugilism and flat noses and thick lips increased, the survey argued, the belief in a link between race and primitive brutality. Yet it also argued that successes in boxing had diversified the views of black men in positive ways. But there were limits to this. A south Londoner might be proud to shake hands with a black sporting personality, the investigation argued, but this did 'not mean that he will necessarily be willing to have him as a permanent visitor in the home or as a husband for his daughter' ${ }^{48}$ Similar paradoxes could be found in music where teenage mods were adopting and championing black musical styles but still sometimes refusing to mix with black people. White adoptions of black cultural forms could thus exist quite distinctly from everyday racial inequities that were structured by much deeper ideas of racial difference. ${ }^{49}$

The complexity of British racial attitudes framed reactions to Ali. His colour rarely entered public discussions of his fight against Cooper in any explicit fashion and it may be that Ali's Americanism actually protected him from overt racial prejudice in Britain since, as

\footnotetext{
${ }^{45}$ See, for example, Elizabeth Buettner, “"This is Staffordshire not Alabama”: Racial Geographies of Commonwealth Immigration in early 1960s Britain', Journal of Imperial and Commonwealth History, 42, 4 (2014): 710-40, at 719-20.

${ }^{46}$ Nava, 'Sometimes Antagonistic, Sometimes Ardently Sympathetic'.

${ }^{47}$ Anthony H. Richmond, The Colour Problem (London: Pelican, 1955), 240-6.

${ }^{48}$ Sheila Patterson, Dark Strangers: A Sociological Study in the Absorption of a Recent West Indian Migrant Group in Brixton, South London (London: Tavistock, 1963), 273, 233-4.

${ }^{49}$ Fuhg, 'Ambivalent Relationships'. Also see Les Back, New Ethnicities and Urban Culture: Racisms and Multi-culture in Young Lives (London: Routledge, 1996), ch. 1.
} 
a temporary visitor, he was not deemed the threat to the whiteness of Britain that immigrants were. When race did enter discussions, it was usually, as with other contemporary black boxers, as a descriptive term. A report in the Daily Mirror, for example, called Ali an 'astonishing young Negro'. ${ }^{50}$ Nonetheless, it is probable that the dislike of Ali owed something to race. Contemporary sociological studies certainly point to a large degree of overt racist talk in semi-private spaces such as pubs and the absence of racism in newspapers, who were often anxious not to enflame racial tensions, is not a guide to popular attitudes. ${ }^{51} \mathrm{~A}$ further complication comes from how racial attitudes were always mixed up with other identities such as masculinity and national identity and, as Bill Schwarz has argued, discussions of race, nation and empire often slid into each other, becoming one and the same. ${ }^{52}$ For example, in reaction to a condescending American report of Cooper's chances, the Daily Mail pointed out that the US allowed black athletes to represent it in boxing and athletics but practised segregation in university sport. It went on to say that the British recognised that Ali was no Paul Robeson - the singer who had done much to develop a positive view of African-Americans in the UK - and posed the question: 'we do wonder why they let the wrong ones out.' It concluded that Ali was adding to the British repugnance of American professional boxing. ${ }^{53}$ This was far from typical of newspaper coverage but it does illustrate that racial prejudice clearly existed in early 1960s Britain, even if it was entwined with attitudes to the US.

Part of that prejudice was the common conception that black migrants found it difficult to adjust to British customs and were 'uninhibited' in a way that did not fit with the unspoken polite customs of much British interaction, particularly when it came to sexual relations. ${ }^{54}$ It is thus probable that there was an unspoken assumption that Ali's behaviour was not just a product of his Americanism but of his race too. Perhaps notable here is that in a review of his chances of becoming world champion, the only reference the Boxing News Annual made to his race was when it claimed 'keeping a tight lip is something this coloured lad has yet to learn or ever will learn'. ${ }^{55}$ Even if an equation of race and a lack of self-control

\footnotetext{
${ }^{50}$ Peter Wilson, 'It must be Cassius’, Daily Mirror, 18 June 1963, 23.

${ }^{51}$ On the reluctance of newspapers to publish racist views see John Davis, 'Containing Racism? The London Experience, 1957-1968’, in Robin D. G. Kelley and Stephen Tuck (eds), The Other Special Relationship: Race, Rights, and Riots in Britain and the United States (London: Palgrave Macmillan, 2015), 125-46.

52 Schwarz, The White Man's World.

53 J. L. Manning, 'Sorry about those Pasty Faces!', Daily Mail, 31 May 1963, 22.

${ }^{54}$ On uncertainties in custom see Michael Banton, White and Coloured: The Behaviour of British People Towards Coloured Immigrants (London: Jonathan Cape, 1959), ch. 6. On uninhibited behaviour see Sheila Patterson, Dark Strangers, 273.

55 'Will it be King Clay?’ 1963 Boxing News Annual and Record Book (London: Ring Publications, 1963$)$ ), p. 7.
} 
was not the intention of the author, it could easily have been interpreted that way by readers and it was probably the product of deeply-set pejorative ideas around racial characteristics. Similarly, cartoon depictions of Ali displayed him with thick lips and a flat nose, two physical features that racial stereotypes often played up. All cartoons exaggerate features and again this might not have been intended as a racial slur. ${ }^{56}$ But such depictions also had a long history of being used as a means of ridicule, something only too evident in the tradition of minstrelsy, and they must have reinforced ideas that Ali was not the equal of a white man. ${ }^{57}$ The uncertainty around how racialized attitudes to Ali were is typical of how slippery and thus insidious racism was. Its proponents often denied any intention and even those who abhorred racism might still accuse those who felt victimised of over-reacting or being overly insensitive. Moreover, the uncertainty of those who were the victims over whether racial prejudice was actually at play could actually make day-to-day living more difficult for people of colour, creating frustration and even bewilderment. ${ }^{58}$ Just occasionally, however, the language lost its ambiguity and revealed the attitudes that were so often hidden. In the wake of the fight, the Daily Express described Ali in the first round as resembling 'a scared piccaninny'. It went on: 'When the blood began to flow, Clay’s brother, Rudolf Valentino, was up howling and barking like some jungle savage'.59

\section{Ali the Muslim World Champion}

The Cooper fight made Ali very famous in the UK and, whether they liked him or not, he fascinated millions. The following year, Ali beat Sonny Liston to become world heavyweight champion and more than 20 million people watched the BBC broadcast of the fight. ${ }^{60}$ The Daily Mail made the news its front-page headline and then published a series of letters from appreciative fans who hoped the outcome would end the anti-Ali stance of the reporter the paper had sent to cover the bout. One concluded 'Clay is a dazzling splash of colour in a sporting world overcrowded by dreary, inarticulate mediocrities. ${ }^{61}$ Like pop music, satirical humour and shorter skirts, Ali was deeply appealing to those in the British

\footnotetext{
${ }^{56}$ For examples of cartoon depictions of Ali see Punch, 12 and 19 June 1963 and 'Another Quick Win and Liston Loses’ Daily Mail, 22 July 1963, 10.

${ }^{57}$ On minstrelsy see Brian Roberts, Blackface Nation: Race, Reform, and Identity in American Popular Music, 1812-1925 (Chicago: University of Chicago Press, 2017).

${ }^{58}$ For a contemporary discussion of the uncertainty around racism see George Lamming, The Pleasures of Exile (London: Michael Joseph, 1960), ch. 4.

${ }^{59}$ Desmond Hackett, 'Yes - Cassius in Five', Daily Express, 19 June 1963, 16.

60 'It's the Fight Game itself That's Sick’, Daily Mail, 18 November 1964, 16.

${ }^{61}$ J. L. Manning, 'Champion Cassius' and G. Griffiths, 'Manning in America', Daily Mail, 26 and 28 February 1964, 1 and 8
} 
public frustrated with the stuffy, staid and stagnated nature of so much in British culture. When Swansea Town reached the FA Cup semi-final in 1964 by unexpectedly beating Liverpool, The People's match report headline was 'Swansea do a Cassius'. ${ }^{62}$ At the semifinal, a fan took to the match a banner that read 'Swansea the Cassius'. Ali had become a byword for style and fighting against the odds.

Quickly after becoming world champion, Ali publicly confirmed his membership of the Nation of Islam, a radical black religious group, and dropped his 'slave name’ Cassius Clay. Two years later, he was drafted for military service in Vietnam and registered as a conscientious objector on religious grounds, causing uproar in America. ${ }^{63}$ Only gradually did the British press show any real interest in the controversy and, since the UK was not involved in Vietnam, it did not have the same significance that it did in the USA. However, America's racial tensions were not irrelevant to Britain. The British media gave considerable coverage to the civil rights movement and the more extreme character of American racial tensions were a counterpoint used to suggest that the UK was tolerant and inclusive. ${ }^{64}$ Moreover, many in Britain were inspired by the civil rights movement and the courage of its advocates. But there was also a fear that the kinds of racial violence witnessed in the American South could erupt in Britain and sympathy for the plight of African Americans was tempered by distrust of activists who might be thought extremist. ${ }^{65}$ Thus there were still British concerns around black power and a sense that the movement's methods were dangerous. ${ }^{66}$ The result was that in the print media there was little sympathy for Ali’s new politics. A Daily Mail writer described some of his behaviour as 'militant' and 'racialist' ${ }^{67}$ A boxing correspondent in the Daily Mirror wrote that he personally detested the 'aims and attitudes of the Black Muslims',

\footnotetext{
${ }^{62}$ Hugh Johns, 'Swansea do a Cassius', The People, 1 March 1964, 24,

${ }^{63}$ For an overview of events and a discussion of race and American boxing more generally see Jeffrey T. Sammons, Beyond the Ring: The Role of Boxing in American Society (Chicago: University of Illinois Press Press, 1990), ch. 7. For a detailed account see David Remnick, King of the World: Muhammad Ali and the Rise of an American Hero (London: Picador, 2000).

${ }^{64}$ Kennetta Hammond Perry, “Little Rock' in Britain: Jim Crow’s Transatlantic Topographies', Journal of British Studies, 51, 1 (2012), 155-77, 173.

${ }^{65}$ On the influence of the US situation on British race relations see Perry, 'Little Rock'. Stephen Tuck, 'Malcolm X's Visit to Oxford University: US Civil Rights, Black Britain, and the Special Relationship on Race', American Historical Review, 118 ,1 (2013), 76-103; Joe Street, 'Malcolm X, Smethwick and the Influence of the African American Freedom Struggle on British Race Relations in the 1960s', Journal of Black Studies, 38, 6 (2008), 932-50; Waters, 'Black Power on the Telly'; Mike Sewell, 'British Responses to Martin Luther King Jr and the Civil Rights Movement, 1954-68', in Brian Ward and Tony Badger (eds), The Making of Martin Luther King and the Civil Rights Movement (Basingstoke: Palgrave, 1996), 194-212; Buettner, "This is Staffordshire not Alabama'.

${ }^{66}$ Waters, 'Black power on the telly'. On British black power see Anne-Marie Angelo, 'The Black Panthers in London, 1967-1972: A Diasporic Struggle Navigates the Black Atlantic’, Radical History Review, 103 (2009): 17-35.

${ }^{67}$ Peter Moss, 'Muhammad Ali Tells Us', Daily Mail, 10 May 1966, 18.
} 
and claimed so did Martin Luther King and Joe Louis. He queried Ali’s 'knowledge, scholarship and political comprehension’ but thought him genuine:

When Clay said to me at Las Vagas last November: “We can’t keep on living like slaves in our masters' country. We can’t for ever be slaves to you white men,” I believe that he was talking the truth as he sees it.

He wanted Ali to be allowed to fight once more before being called up to stop him achieving the status of martyrdom. ${ }^{68}$

The British press also seemed reluctant to drop what Ali regarded as his slave name. In 1965, the Daily Express had even contemptuously written 'Clay - or Mohammed Ali Oop or whatever he calls himself' ${ }^{69}$ This was common in America too, where it was a deliberate refusal to bow to Ali's racialized politics, and it was employed by both white journalists and black American moderates. ${ }^{70}$ In the UK, where the link between Islam and black power was less understood and less important, the continued use of the name Clay was probably more often unthinking. Indeed, it might even have been to ensure readers and viewers knew who was being referred to. The Tatler, for example, in 1966 called him Ali but then added 'or Cassius Clay as he is still generally called'. ${ }^{71}$ Nonetheless, not all boxing fans approved and one Essex fan wrote to Boxing News that same year calling its continued use of the name Clay 'disgraceful'. ${ }^{72}$

Outside the newspapers, there was little evidence of active hostility to Ali because of his new politics. Indeed, the fact that support for Ali had not collapsed with his new politics infuriated some in the British print media. ${ }^{73}$ British television continued to interview him and Ali could not resist showing off for the cameras with his jokes, banter and even singing and dancing. Such was the interest in Ali that his fights were televised in Britain in a way that other leading bouts were not. This was enabled by the development of live satellite broadcasts that could be shown either on television or at the cinema. ${ }^{74}$ In 1965,7 million Britons watched the live broadcast of his second bout with Liston, despite it being on

\footnotetext{
${ }^{68}$ Peter Wilson, ‘Let Clay Fight Go On!’, Daily Mirror, 2 March 1966, 27.

${ }^{69}$ Desmond Hackett, '007 Floyd plots exit', Daily Express, 18 November 1965, 18.

${ }^{70}$ Murray G. Phillips, Gary Osmond and Stephen Townsend, 'A Bird's-eye View of the Past: Digital History, Distant Reading and Sport History’, International Journal of the History of Sport, 32, 15 (2015): 1725-40.

71 'London Life', The Tatler, 6 August 1966, 3.

72 M. Draycott, 'Changed Name’, Boxing News, 12 August 1966, p. 7.

${ }^{73}$ J. L. Manning, 'No Hiding Place for the Greatest', Daily Mail, 4 March 1966, 18.

${ }^{74}$ For boxing on television in this era see Richard Haynes, BBC Sport in Black and White (Basingstoke: Palgrave 2016), ch. 9.
} 
television at 3.30am. Another quarter of a million listened in on the radio. ${ }^{75}$ Ali won in the first round and there were questions about whether Liston had gone down of his accord rather than because of a punch. Yet this simply added to Ali's fame and mystique.

\section{Cooper versus Ali 1966}

The controversy over Ali's drafting was ongoing when he fought in Britain for a second time. The bout was again against Cooper but now for the world title, the first time a heavyweight title fight had been fought in the UK for 58 years and a location partly chosen because of fears that Ali might say something about race that could alienate American boxing fans. ${ }^{76}$ Britain had also never had a world heavyweight champion and thus the fight seemed a moment of reckoning for British boxing. There was little overt focus on Ali's politics in the build-up and instead it was again portrayed as a fight between a controversial but charismatic American and the quintessentially English 'our 'enry', with the 'common touch' ${ }^{77}$ This image was not discouraged by Cooper or the promoter and was probably an easier 'sell' in box office terms that anything that dragged in Ali's politics. In an interview for ITV, Cooper spoke of his ordinary working-class roots on a council estate and his labouring days, while the reporter pointed to his 'trim suburban home'. Yet Cooper did not bite at attempts to get him to say he hated Ali or that the American was the type of person he might hit if he was not a boxer. Instead, Cooper said Ali was entitled to his beliefs and that he had nothing against Muslims. ${ }^{78}$ Ali, meanwhile, was far more subdued when he reached Britain and at times consciously refused to play up to his image. ${ }^{79}$ His new persona intrigued and confused the media and fans alike. The Observer's boxing correspondent said that since Ali's conversion, he had come to 'seem infinitely complex, in turn charming, nasty, arrogant, humble, friendly, aloof, hilarious, humourless, brilliantly alert and weirdly uninformed' ${ }^{80}$ But interest in Ali and the fight was again huge. When the BBC and ITV were outbid for the British live television rights by a cable service, the government intervened and ensured a live radio broadcast and a television showing the next day. ${ }^{81}$ Perhaps the clearest sign of the interest was the fact that Ali was invited to a meeting with the ever publicity-conscious Harold

\footnotetext{
75 ‘7m Early Birds’, Daily Mail, 2 June 1965, 1.

${ }^{76}$ Ezra, Muhammad Ali: The Making of an Icon, 85.

${ }^{77}$ For an example of such reporting see Peter Wilson, ‘The Vision of Cooper’, Daily Mirror, 18 May 1966, 30.

78 'ITN Reporting 66: Clay/Cooper Training for World Heavyweight Title', 27 April 1966. Online at http://www.gettyimages.co.uk/license/828118170 (accessed 6 September 2019).

79 'World Heavyweight Boxing Champion: Cassis Clay', 9 May 1966. Online at: http://www.gettyimages.co.uk/license/813068846 (accessed 6 September 2019).

${ }^{80}$ Reproduced in Hugh McIlvanney, McIlvanney on Boxing (Edinburgh: Mainstream, 1996), 29.

${ }^{81}$ House of Commons Debates, 11 May 1966, vol. 728 cc. 72-3W.
} 
Wilson, even if it did end up being cancelled to allow the prime minister to meet the Seamen's Union who were threatening to strike. ${ }^{82}$

The warmer welcome that Ali received owed much to how rapidly parts of British culture had changed between 1963 and 1966. The social and cultural changes of the 1960s may have begun in the 1950s (and in some cases before) but it is difficult to deny how they gathered pace as the decade moved on. ${ }^{83}$ Music, fashion and the morals, or least perceptions of the morals, of the young shifted significantly as Britain began to 'swing'. In a climate where pop music was everywhere, boys had longer hair and girls had shorter skirts, and there was open discussion of sexual freedom, a ranting arrogant American simply was not the affront it once had been. Even politics had changed. A Labour government was elected in 1964 on a modernizing manifesto that promised a 'New Britain', and it was happy to give the wider cultural shifts a stamp of establishment approval by awarding the Beatles MBEs. Indeed, Ali himself was seeing something of the new British society. A man who spent time with him in London noted how the champion was inundated with assertive offers of marriage and sex from young white and black women. ${ }^{84}$

However, not everyone had moved on and, as Donnelly argues, for many the 1960s were 'a party that was happening somewhere else' ${ }^{85}$ Cooper recalled in his autobiography:

old ladies in cars who used to stop, wind down the window and wish me luck - old dears, butter wouldn't melt in their mouths, or so you'd think. They might not be interested in boxing normally, but here they were telling me to knock poor old Ali senseless, button his lip, do him up, all that sort of thing. I don't think it was colour prejudice. If he had been a white boy they would still have said it. Clay, or Ali as he called himself then, was a big mouth by American, let alone English standards. ... [I]f you boast and say what you're going to do to your opponent over here in Britain they loathe you. ${ }^{86}$

But Cooper did judge Ali, or least his previous successes against other black boxers, in racial terms. He thought Ali could more easily ‘out psych’ black fighters than white ones, half beating them before the fight had even started:

\footnotetext{
${ }^{82}$ Walter Terry 'It's a Bit Rough, the Queen Bringing Harold into Politics’ Daily Mail, 16 May 1966, 6.

${ }^{83}$ For an overview of the 1950s in Britain and their significance as a period of change see Nick Thomas, 'Will the Real 1950s Please Stand Up?', Cultural and Social History, 5, 2 (2008): 227-23.

${ }^{84}$ Michael Abdul Malik, From Michael de Freitas to Michael X (London: Sphere Books, 1968), 177-8.

${ }^{85}$ Mark Donnelly, Sixties Britain: Culture, Society and Politics (London: Routledge, 2005), xi-xiii.

${ }^{86}$ Cooper, An Autobiography, 114. 115.
} 
It happens with the coloured boys more often because they are more gullible or susceptible. It's not a lack of concentration so much as their upbringing and way of life. They're more flamboyant and they tend to take things at their face value more readily. They're either on top of the world or they're down. We delve into things a bit more and don’t believe so easily.

Ali, he thought, was different to other black fighters, with self-belief and power from his religious belief and following. ${ }^{87}$ The UK may not have had anything like the overt racial tensions that made Ali so controversial in the USA but, as the comments of Cooper showed, the sense of 'us' and 'them', of racial difference, was profound, even amongst many of those who would have been horrified to think of themselves as racist or prejudiced. Moreover, as Cooper's comments also show, this sense of otherness was not just about difference; it was also shot through with a sense of white superiority.

Although there was an attendance of 42,000, the fight itself did not sell out and touts complained they could not shift their stock because no one thought Cooper's eye would last the duration. ${ }^{88}$ In the UK, it was only live on pay-tv and in the cinema but 13 million listened on the radio to Ali repeat a straightforward win after Cooper received another cut eye. ${ }^{89}$ Those in attendance were angry because it appeared that the cut had been caused by Ali's head rather than fist. At the end, there was booing and pandemonium as fans invaded the ring and police had to intervene. At least one boxing reporter saw a racial dimension to the crowd's anger:

In my opinion he is a champion of the utmost class, irrespective of his colour. That such disgraceful things should happen in Britain where people can walk the street unashamed of their colour or creed is a damming reflection on those extremists to whom sportsmanship takes second place. ${ }^{90}$

Yet other reports overlooked or ignored the incident. Ali himself said that the British public

\footnotetext{
${ }^{87}$ Cooper, An Autobiography, 115, 162

88 J. L. Manning, 'Simply, This is How They Can Stop Becoming Cheap Horror', Daily Mail, 23 May $1966,18$. 'Cooper's Cut not Caused by Head Butt' The Times, 23 May 1966, 5.

${ }^{89}$ Tanner, Ali in Brtiain, 71. Ezra, Muhammad Ali, p. 112. British commentators were divided in whether they called the champion Ali or Clay. For an example of British commentary see 'Muhammad Ali vs Henry Copper II’, https://www.youtube.com/watch?v=sXo0FqZaRUE\&feature=youtu.be (accessed 6 September 2019)

${ }^{90}$ Alan Wood 'Ice-cool Clay clips Cooper down to size', Western Mail, 23 May 1966, 16.
} 
had cheered him and 'everything went off perfectly'. ${ }^{91}$

The following night, Ali made a charismatic appearance on the Eamon Andrews chat show, where he spoke of how he did not like hitting a man covered in blood. This seemed to be a real turning point in how he was seen in the UK. A Coventry housewife wrote to the Mirror after seeing it: 'I used to dislike him intensely, but now I'm a fan'. ${ }^{92}$ Three months later, when Ali fought again in Britain, Boxing News ran an editorial thanking Ali (although it still called him Clay) for boosting interest in British boxing. It said that he had been 'a model of good temper and careful speech' who had not given offence in Britain in 'any shape or form' and that the editor found himself liking Ali 'in spite of what we had read or heard of his antics and utterings' before and after winning his title, the time when he had announced his conversion. It concluded that Ali would always be welcome back in Britain, as citizen or champion. ${ }^{93}$

\section{Ali versus London and his dethronement}

Ali's third UK fight, and his second of 1966, was against Brian London, who few gave much of a chance. London put up a pitiful performance and was knocked out in the third round. Boxing News called his showing 'pathetic'. Fans booed at the end and felt cheated of a proper contest; there were rumours of a board of control inquiry into a mismatch. But the fight also seemed to confirm Ali's vast superiority over anything or anyone the UK could produce and now he was no longer a threat to any British chance of a heavyweight champion the path was cleared for his popularity to grow further. A letter to Boxing News said Ali would become 'the greatest heavyweight champion the world has ever known'. Another complained that the criticisms being aimed at London and the way he was being made to feel that he had let his country down were because people would not recognise Ali as the 'great and unique champion he is'. Not everyone was convinced and another letter argued Ali was only the greatest because 'he lives in an era of the poorest bunch of heavyweights ever in the history of boxing, ${ }^{94}$

In 1967 Ali again refused to be enlisted and was convicted of draft dodging and stripped of his title and licences to box. The Times ran an editorial on the affair. It thought his beliefs genuine but that he had shown himself to be 'vain, cruel, and continuously

\footnotetext{
91 'King Cassius Holds Court', Daily Mirror, 23 May 1966, 15.

92 'Cassius is REALLY the greatest', Daily Mirror, 28 May 1966, 12.

93 'Clay’s Example’, Boxing News, 5 August 1966, 6.

${ }^{94}$ Letters in Boxing News, 19 August 1966, 5.
} 
provocative'. ${ }^{95}$ However, British opinion around the Vietnam war was generally ambivalent or hostile and The Times was out of kilter with the general tone of British feeling, which now seemed to judge Ali as a boxer and man of principle rather than the racial or national threat he was in the USA. ${ }^{96}$ For all the British fears of racial extremism that sometimes existed, the racial significance of his religious resistance simply did not resonate in the UK where Islam was associated with Asian migrants rather than black power. Moreover, conscientious objection on religious grounds was an accepted principle that had not even not created significant controversy during the Second World War. ${ }^{97}$ The sympathy towards Ali, although tinged sometimes by a concern that it might represent something bigger, was apparent when in 1969 London Weekend Television ran a half hour show on Ali that gave him a full platform to discuss his belief in the need for black liberation. Direct editorial comment was minimal, although the show concluded that Ali knew the 'latent power' he held but did not 'have the maturity to control it' ${ }^{98}$ There was much sympathy for Ali in the boxing establishment too. The Boxing News declared that he was still the best heavyweight in the world. ${ }^{99}$ One fan organized a petition to have Ali recognised as world champion and collected more than 22,000 signatures in Britain. ${ }^{100}$ The different views of boxing fans across the Atlantic became evident in 1970 after a computer-simulated fight between Ali and another iconic boxer Rocky Marciano. In the US, Marciano’s win was a 'soothing tonic' to those who wanted to see Ali put in his place but there was such anger from British boxing fans that the simulation was rerun with a different result. ${ }^{101}$

Ali's British popularity suggests limits to the extent that contemporary understandings of race relations in the USA and UK were entangled but it does not mean Britain was becoming more accepting of racial diversity. Indeed, if anything the opposite was happening. In a 1967 survey of immigrant experiences, there were widespread reports of open hostility in public places and problems in finding housing, employment and even car insurance. Some respondents reported experiencing more hostility and prejudice the longer they lived in

\footnotetext{
95 ‘Called-Up Champion’, The Times, 29 April 1967, 11.

${ }^{96}$ On British attitudes to Vietnam see Caroline Page, US Official Propaganda during the Vietnam War, $1965-$ 1973 (Leicester: Cassell, 1996).

${ }^{97}$ Rachel Barker, Conscience, Government and War: Conscientious Objectors in Great Britain (London: Routledge, 1982).

98 This can be watched online at 'Ali’s 1969', https://www.youtube.com/watch?v=U2S2KFGfdyc (accessed 6 September 2019).

99 'Muhammad Ali and Boxing News', Boxing News, 30 June 1967, 1.

100 Tanner, Ali in Britain, 39.

101 Sammons, Beyond the Ring, 209.
} 
Britain and just over a third thought life had become more difficult. ${ }^{102}$ In 1968, the year that Ali was denied the right to appeal against his conviction for refusing the draft, Parliament passed the Commonwealth Immigrants Act, taking away the right of entry from British passport holders without grandparents born in the UK. In the same year, Enoch Powell made his infamous Rivers of Blood speech, which pointed to the situation in the USA and predicted widespread violence unless British immigration was curbed. It legitimized overt racial bigotry and took it from the private sphere into the public realm. Opinion polls suggested that some threequarters of the population agreed with Powell. ${ }^{103}$ Nor had boxing become colour-blind. Until 1968, British championships were limited to those born in the UK or Ireland and thus denied to black boxers who had moved to Britain as children. That rule was changed but in 1969, the Boxing News could still write of a 'New White Hope' in discussing up and coming fighters. ${ }^{104}$

Ali did not fight between March 1967 and October 1970 which meant his media coverage in the UK was far more limited than it might otherwise have been. His absence coincided with the period when concerns around black power intensified in the UK and USA. ${ }^{105}$ Perhaps had he fought in the UK in 1968 or 1969, with the furore around black power and Powell's speech at its height, white British reactions might have been different. But that is speculation and, as it was, in the public sphere Ali seemed disconnected from the everyday racial tensions within the UK. Yet the parallels that those both in favour and opposed to immigration continually drew between the racial situations in the US and UK meant that beyond the newspapers and television screens Ali’s significance was never just as a great boxer.

This was especially true for black Britons. This was a small and diverse population, with no political representation. Black figures were rare on television and when colour was discussed it was usually as a problem. ${ }^{106}$ The civil rights movement, like black sporting successes, however showed something more positive and watching this on television contributed to a growing sense of black consciousness in the UK. Particularly important here was the black power salute given by two US athletes on the medal podium at the 1968 Olympics. Ali may not have offered a similar single iconic moment but his general career

\footnotetext{
${ }^{102}$ W. W. Daniel, Racial Discrimination in England (London: Penguin, 1968), 42, 50.

103 Schwarz, White Man's World, 19, 48.

104 'New White Hope', Boxing News, 24 October 1969, 1.

105 On its intensification see Waters, 'Black Power on the Telly', 963.

${ }^{106}$ Sarita Malik, Representing Black Britain: A History of Black and Asian Images on British Television (London 2002). Schaffer, The Vision of a Nation.
} 
and position was an inspiration to many people of colour in the UK. ${ }^{107}$ For some, this inspiration was more direct. Michael X, a British black power activist, met Ali before both the second Cooper fight and the bout against Brian London. He took him into immigrant communities in London, where Ali created 'an aura of excitement', captivating 'everyone he met', and later to speak to a number of bodies such as an Islamic Students Group. ${ }^{108}$ Michael X told the Daily Mail that Ali's visit to Notting Hill had 'brought a great deal of comfort' to people in what was a 'black ghetto'. The reporter, however, did not seem impressed; he questioned the need for 24 bodyguards to be there and asked if Ali was being used to promote the aims of 'British Black Muslims' and the Racial Adjustment Action Society. ${ }^{109}$ Again, the British press seemed to miss Ali's greatest significance: the way Ali was becoming part of what Kelley and Patterson have called a 'black globality’, a transnational racial identity and understanding of race relations. ${ }^{110}$

\section{Conclusion}

C. L. R. James famously argued 'What do they know of cricket who only cricket know?'111 By this he meant that the game could not be understood without looking at its social and cultural context. The same is true of boxing in the 1960s and its dynamics were entwined with the politics of race and immigration. Black boxers, like all black men and women, in Britain were always regarded as 'other' and there was a complex array of assumptions about racial difference. Ali and the wider sport reinforced stereotypes around black physicality and temperament but boxing was also a shared culture that cut across racial lines and it was a rare space where black achievements were openly celebrated and admired, even if that celebration was not conceptualised along racial lines and did not stop the endemic casual racism people

\footnotetext{
107 Waters, 'Black Power'. Malchow, Special Relations, 171. Ali: Me, My Family and Muhammad Ali, BBC Radio 4 Extra, 26 April 2016.

108 Malik, From Michael de Frietas, 174-5. Stokely Carmichael and Michael Thelwell, Ready for Revolution: The Life and Struggles of Stokely Carmichael (London: Scribner, 2003), 576-77. On differences and influences from American black power in the British movement see Rosie Wild, "Black Was the Colour of Our Fight”: The Transnational Roots of British Black Power’, in Robin D. G. Kelley and Stephen Tuck (eds), The Other Special Relationship: Race, Rights, and Riots in Britain and the United States (London: Palgrave Macmillan, 2015), 25-46. Ali also later visited Muslim communities in the UK, inspiring them into more racially aware positions.

109 The Ali connection was enough to lead one journalist to attend a meeting of the group. His report was nonjudgemental and unlikely to shock any reader. Peter Duffy, 'Note the Bodyguard', Daily Mail, 19 May $1966,7$. 110 Tiffany Ruby Patterson and Robin D. G. Kelley, 'Unfinished Migrations: Reflections on the African Diaspora and the Making of the Modern World', African Studies Review, 43, 1 (2000): 11-45. This drew upon a longer tradition of people of colour in the UK having a global sense of a black identity and an international understanding of race relations. See Marc Matera, Black London: The Imperial Metropolis and Decolonization in the Twentieth Century (Oakland: University of California Press, 2015).

${ }^{111}$ C. L. R. James, Beyond the Boundary (London: Stanley Paul, 1963).
} 
of colour in Britain faced on a daily basis. The revulsion that boxing sometimes engendered - something all too apparent in reactions to the pictures of a bloody Cooper after his fights with Ali - limited the impact that Ali had but the extensive media coverage he received meant his impact went far beyond other contemporary black boxers who struggled to gain media exposure and fights in a sport that was in decline beyond its very pinnacle. ${ }^{112}$ However, criticism of Ali was as much rooted in his national identity as his colour, a reminder of how wider racial prejudices and tolerances were always entwined with concerns around nationhood and gender. This increased their slipperiness, masking the depth of racial attitudes that did exist which, in turn, helped white Britons feel better about their country but added to the sense of dislocation immigrants and Britons of colour could feel.

The Britain that viewed Ali was not a straightforward place. There were those who regarded its culture and identity as under assault from Americanization and immigration but there were also those who accepted the modernization, glamour and diversity that these forces were bringing. Probably, over time, Ali, like other black sportsmen, musicians and entertainers, helped shift the pendulum from the former to the latter. But this was a gradual process and one where shared symbols and experiences still existed within deeply unequal power relationships between black and white and dominant discourses rooted in colonial attitudes. Yet Ali's most important significance in the UK was not for white Britons or the emergence of multiculturalism. It was for black Britons for whom he was a figure of inspiration at a time when there were so few other icons of colour. The UK may not have been uniformly racist but it was not a land of racial equality either and in that context Ali was a source for dignity and respect for Britons of colour.

\footnotetext{
112 See Johnes and Taylor, 'Boxing, Race and British National Identity'. In the aftermath of the first Cooper-Ali fight, the Daily Herald (20 June 1963) ran a front-page story decrying the savagery of the sport.
} 